\title{
PRESCHOOL EDUCATION STUDENTS'ATTITUDES ABOUT THE POSSIBLE IMPACT OF MUSIC ON CHILDREN'S SPEECH DEVELOPMENT
}

\begin{tabular}{l}
\hline \multicolumn{1}{c}{ Dr. Bačlija Sušić Blažen } \\
\hline A R T I C L E I N F O \\
Original Research \\
Received: November, 26.2018. \\
Revised: February, 08.2019. \\
Accepted: February, 14.2019. \\
doi:10.5937/ijcrsee1901073B \\
UDK \\
316.644-057.875:[37.036-053.4:78 \\
371.3::78-028.31
\end{tabular}

Keywords:

multi-modal activities, music education,

preschool education, speech development, students.
E-mail: blazenka.baclijasusic@ufzg.hr

\section{A B S T R A C T}

Music and language are means of human communication, whose common medium is the sound occurring in a unit of time. Numerous relevant studies show that the constant implementation of various forms of musical activities influence the development of a child's speech and motivates the development of pre-reading skills. A survey formed for the purpose of the study explored the positions of the students of the part-time studies of Early and Pre-school Education on the use of musical, creative musical, and multi-modal activities in their immediate methodical practice, as well as their possible impact on children's speech development. The results of the study show that the participants believe that the development of a child's speech is most influenced by musical activities containing multiple verbal elements (children's singing games, songs and counting rhymes) which are more frequently carried out in practice. Although the participants believe that the activities of rhythmical speech and creating a text to an existing melody influence the development of a child's speech the most, it is more common in practice to conduct creative musical activities, such as listening to music while dancing and/or painting, as well as those activities related to sound sensitivity, which may be due to the competences of the participants in the listed areas. The respondents who believe that multi-modal activities contribute to the development of a child's speech, often carry them out more frequently in their methodical practice. The results of the study represent a significant contribution to the further improvement of educational practices.

(C) 2019 IJCRSEE. All rights reserved.

\section{INTRODUCTION}

Based on the point of view that musical potential is universal, as is the linguistic ability (Wallin et al., 2000), there are numerous links between music and language. Their primary means of communication and their common medium is sound organised in time (Shelemay et al., 2001). Kraus and Slater (2015) observe music and language within the context of human communication pointing out that both systems of communication were derived from the basic structure of sound, its inherent har-

\footnotetext{
Corresponding Author

Dr. Bačlija Sušić Blaženka, University of Zagreb,

Faculty of Teacher Education, Croatia

E-mail: blazenka.baclijasusic@ufzg.hr

\section{cc) (†) $९$}

This work is licensed under a Creative Commons Attribution - NonCommercial - NoDerivs 4.0. The article is published with Open Access at www.ijcrsee.com
}

monic and temporal properties. Given their common origin, their complementary strength can be expressed and play an important role in the development of human cognition and learning.

The relationship between music and language is further revealed by the similarities in our neural structure during their processing, as well as the cognitive processes specifically linked to certain domains. Dunbar (1996) interprets evolutionary evidence in such a way that speech, as a form of communication, was developed during human development and use of music. Such an interpretation explains the significant overlap of linguistic and musical neural networks contributing to better language learning (grammar, vocabulary, and pronunciation) in children who receive music education. This is further confirmed by recent studies which also point to the common functions of music and speech (Tallal and Gaab, 2006), as well as their mutual influence (Jäncke, 2012). In their study of the influence of 
the tonal function of individual chords on the syntactic and semantic text processing, Hoch et al. (2011) concluded that the neural and the psychological sources of music and language processing overlap to a high extent.

Some authors generally see the similarity between musical and phonological, i.e. prosodic structures of language, which is the result of a common nature of music and language as a sequence of sounds organised in time (Samson, Ehrlé and Baulac, 2001; Lerdahl, 2001). Considering the similarities and differences in the processing of pitch in speech and music, Friederici (2017) believes that the information about the pitch plays a key role in processing prosody in language, as well as in processing melody in music. In addition, phonological awareness is regarded as a key factor in the development of reading and writing skills (Dege and Schwarzer, 2011; Loui et al., 2011). The same authors also believe that preschoolers can benefit from music classes in order to increase their phonological awareness.

The relationship between musical and linguistic development is particularly reflected in the early stages of child development, as indicated by the phenomenon of communicative musicality. It represents the interaction between mother and child, which is, in the early years of a child's life, a dialogue formed by the elements of rhythm, vocal forms, body movements, and narrative elements (Trevarthen and Malloch, 2002, Trevarthen, 2012). Communicative musicality is a key component of a child's early communication which represents fundamental and innate form of child's expression based on his/her appreciation of musical patterns. It is an intrinsic organizing principle, a form of conversation between infant and parents/caregivers in which child may enter minutes after birth. The child is being engaged into the rhythms and melodies of a conversation using form of vocal narratives with body gestures in order to converse emotionally with others.

This communication is based on a dialogical vocalisation which relies on musical elements including pitch, rhythm, dynamics, and timbre. Such a communication forms the foundations of further linguistic and musical development in infants and young children (Trehub, 2003a, 2003b).

There are also other benefits of communicative musicality such as influence to numerous aspects of human development including the development of the child's identity (Trevarthen, 2002), the use of art in the development of human thought and activity
(Dissanayake, 2001, 2002), and the child's early creative expression in music (Barrett, 2006). Barrett (2011) points out that there is still a small number of researches focused on children's early vocalizations and music interactions through which they realize their identity as a musical and social beings

There is increasing evidence indicating that speech functions can benefit from musical functions, and vice versa (Jäncke, 2012). Musical and linguistic activities are, therefore, spontaneously integrated in the child's daily activities from its early age. The Japanese musical pedagogue Shinichi Suzuki based his musical-pedagogical concept on the relationship between speech and music, noting that the child's ability to learn their mother tongue is an indicator of its hearing development. Therefore, he believed that children should use such a natural method, used in language learning, in their musical education as well. The specificity of the Suzuki method is the learning of playing a musical instrument on the model of speech learning (through listening, observation, and imitating), and the author stresses the period between the child's third and fifth year of age as the most suitable for such a method of musical education (Bačlija Sušić, 2016).

In music, the word also represents a means of its expression, along with sound or tone. Numerous musical activities, based on performance and reproduction of learned songs, counting rhymes, singing games, etc. as well as creative musical activities focused on process of music podruction include verbal elements. Creative musical activities include acitivities such as: sung speech, rhythmic speech, creating lyrics to accompany existing melodies and vice versa, creating melodies to accompany existing lyrics (setting verses to music), etc.

Denac and Škorjanec (2017) emphasize the role of language in musical activities such as singing songs, listening to music, and playing music. The author points out the balanced relationship of text and melody in musical designing of a text, in such a way that at one time, the text is in the foreground (speech parts are inserted into melody), and at another, melody illustrates events through sounds (onomatopoeic expressions). The authors also point out that in selecting songs, the preschool or schoolteacher's role is to select a song with a clear and simple text that a child can understand, which will also contribute to the child's linguistic, musical, or singing ability. When listening to music, a child creates his/her own representation of the musical work based on 
his/her impression and perceptual abilities and expresses it in a syncretic way (through movement, drawing, speech, etc.). This syncretic expression also contributes to the development of his/her creative, i.e. productive potential.

Jewit and Kress (2003) call this organised collection of various means of creating meaning, which can include images, looks, gestures, movement, music, speech, and sound effects, a multi-modal expression, i.e. a multimodal way of communication. It is, thus, created by a combination of different modes (image, text, appearance, music, movement, speech, moving images) which contribute to the richness of creative expression. Van Leeuwen (2005) defines the multi-modal concept as a combination of different semiotic ways, such as language and music, in a communicative creation or occurrence.

Although Vygotsky (1978) emphasizes language as the most important "instrument of communication", Mercer and Littleton (2007) believe that language is not a single, but a broad set of instruments. We, therefore, use a variety of semiotic means in communication, including different movements, sounds, music, drawings, images, etc., along with speech, gestures, etc. This is also confirmed by Pramling and Wallerstedt (2009), who believe that different ways/modes of communication are transmitted and combined. Thus, for example, we tend to use various non-verbal forms of communication, such as making certain gestures when speaking (Iverson and Goldin-Meadow, 1998; Kendon, 1997), which represent semantic means of the non-verbal type (Vygotsky, 1978; Säljö, 2005). With the help of various forms of communication, we are capable to better express our impression of the world around us, as well as to affect other people's impressions.

\subsection{Relevant research on the connection between music and language}

Numerous studies point to the connection of music and language in children's early age. Starting with the common nature of music and language, based on the natural patterns of sounds and silence, Chen-Hafteck and Mang (2012) consider music as a means of language learning. They claim that this is also indicated by brain studies which confirm the similarities in the processing of musical and linguistic information. Furthermore, numerous studies cite practice examples in working with young children where songs and other musical activities are used to improve children's linguistic skills (Dahlbäck, 2011; Still, 2011). The potential link between musical and linguistic skills is also confirmed by a significant positive correlation between different competencies observed in various studies: pitch and phonemic discrimination (Lamb and Gregory, 1993; Anvari et al., 2002); rhythm and prosody (Patel, 2006); rhythmic ability and reading (Douglas and Willats, 1994) and recalling certain melodies and connecting them with texts (Harms et al., 2014). Along with these correlation studies, there are also experimental studies exploring the influence of music learning on linguistic skills, such as the study conducted by Strait and Kraus (2011) which concluded that musical abilities were a significant predictor accounting for over $40 \%$ of variance in reading skills among children aged 8-13 with little or no musical education. The same authors concluded that the connection between language and music processing is particularly expressed in rhythmic skills.

On the other hand, there are studies focused on how exposure to a certain language influences musical ability, showing that language, among other things, has a significant impact on a child's singing ability (ChenHafteck and Mang, 2012). These authors studied how the use of different languages (Cantonese and English) and their tonal height influences tonal precision in children's singing, depending on the language they speak.

Moyeda, Gómez, and Flores (2006) studied the connection between musical and linguistic skills through a specially designed program of musical activities aimed at creating differences between the elements of melody and rhythm, and the connection of auditory stimuli to visual and motor activities. The effects of this program and the program called Rhythms, songs and games were evaluated and compared to the vocabulary of preschool children and the vocabulary of those children who were not exposed to any of the above two programs. The results of the study showed a significant increase in the receptive vocabulary in the group of children exposed to the program which included musical activities.

Walerstedt (2013) believes that there is a symbiotic relationship between music and language in children's development and that in very young children, the two are so close that they are the same. The environment in which the child is brought up also represents a significant factor. 
Jeremic (2018) describes the connection between language and music as a dynamic relationship in which work in one area also contributes to the development of the other.

It is important that during their growing up, children still experience the close connection between music and language, since, because of environmental influence, they can acquire and experience them differently (Chen-Hafteck and Mang, 2012).

In addition to these studies, the concept of multi-modality has, in recent years, been the subject of numerous studies related to upbringing and education, especially regarding the new literacy perspective (Bourne and Jewitt, 2003; Kress, 1997), natural sciences (Jewitt et al., 2001), as well as the artistic field, visual arts (Wright, 2007) and music (Finney, 2003; Vandivere (2008); Walker, 2004; Pramling and Wallerstedt, 2009).

Vandivere (2008) believes that communication in music education which includes different facial expressions, gestures, and body movements, is a crucial teaching strategy and the indicator of the students' comprehension, as well as the satisfaction of their needs. Based on the view that different communicative ways/modes are transmitted and combined, Pramling and Wallerstedt (2009) studied the connection between sound (nonverbal) and verbal aspect within the framework of music education of children aged 4-8. They investigated the way in which children react/respond to tasks in which they face a challenge of talking about the music they experience/learn about. They analysed the semiotic means that the children and their educators/teachers used, as well as the way of their transformation from one modality to the next (verbal, sound, colours, and gestures).

\section{METHODOLOGY}

\subsection{The respondents}

A total of 125 respondents participated in the study, of which 123 were female $(98.4 \%)$ and 2 were male $(1.6 \%)$. The largest number of respondents was aged 22-32 $(\mathrm{N}=79 ; 63.2 \%)$, and there were 36 respondents aged $33-43$, that is, $28.8 \%$. The smallest number of respondents was aged 44-54 $(\mathrm{N}=6$; $4.8 \%)$, and 4 respondents $(3.2 \%)$ did not indicate their gender.

Of the total number of respondents, $95.2 \%(\mathrm{~N}=119)$ were employed in a preschool at the time of the research, while only
$4.8 \%(\mathrm{~N}=6)$ were not employed. Approximately half of the respondents, $51.2 \%(\mathrm{~N}=64)$ said that they could play a musical instrument, $46.4 \%(\mathrm{~N}=58)$ that they did not, and $2.4 \%$ $(\mathrm{N}=3)$ did not state whether they could play an instrument. Most respondents, $85.6 \%$ of them $(\mathrm{N}=107)$, said that they did not undergo additional music education, and $14.4 \%(\mathrm{~N}=18)$ stated that in addition to school and/or university, they had attended additional forms of music education.

\subsection{Measuring device and procedures}

Questionnaire was constructed for the purposes of this study. Alongside the initial respondent data it included the following subscales: respondents' opinions on the possible effects of musical, creative musical activities, and multi-modal activities on children's speech development, the frequency of conducting these activities, the views and opinions on the competencies they would like to additionally improve during their graduate studies, and the conditions for conducting these activities in educational practice.

Descriptive and inferential statistics were used in the study, and the SPSS statistics program was used to calculate the data.

\subsection{Purpose and objective of the study}

The problem of the study was to examine how the part-time students of the graduate Early and Preschool Education studies Faculty of Teacher Education in Zagreb, Croatia, assessed the possible influence of musical activities, creative musical activities, and multimodal activities on speech development. The aim of the research was to examine their opinions and attitudes on the potential impact of individual musical activities, creative musical activities, and multi-modal activities on speech development, the frequency of conducting these activities in educational practice, and their mutual relationship.

\subsection{Hypotheses of the study}

In accordance with the above problem and the purpose of the study, the following hypotheses were established:

H1 Respondents believe that musical 
activities that have more verbal elements contribute to children's speech development

H2 Respondents believe that creative musical activities which include more verbal elements and multi-modal activities contribute to the children's speech development

H3 Respondents frequently conduct musical and creative musical activities which include more verbal elements in their educational practice

H4 Respondents frequently conduct multi-modal activities in their educational practice

H5 There is a significant correlation between the respondents' opinions on the impact of individual musical and creative musical activities on children's speech development and the frequency of their implementation in educational practice

H6 There is a significant correlation between the respondents' opinions on the impact of multi-modal activities on children's speech development and the frequency of their implementation in educational practice.

\section{RESULTS}

The average values indicating which of the mentioned musical activities respondents believe most influence children's speech development are shown in Table 1.

Table 1. Respondents' opinion on the possible impact of a musical activity on children's speech development

\begin{tabular}{lll}
\hline & $\begin{array}{c}\text { The } \\
\text { arithmetic } \\
\text { mean }\end{array}$ & $\begin{array}{c}\text { Std. } \\
\text { deviation }\end{array}$ \\
\hline $\begin{array}{l}\text { Song acquisition and repe- } \\
\text { tition }\end{array}$ & $\mathbf{4 . 3 6}$ & $\mathbf{0 . 7 0}$ \\
\hline $\begin{array}{l}\text { Counting rhyme acquisi- } \\
\text { tion and repetition }\end{array}$ & $\mathbf{4 . 4 3}$ & $\mathbf{0 . 6 3}$ \\
\hline $\begin{array}{l}\text { Children's singing games } \\
\text { Playing hand-crafted rat- }\end{array}$ & $\mathbf{4 . 5 8}$ & $\mathbf{0 . 5 8}$ \\
$\begin{array}{l}\text { tles or instruments from a } \\
\text { children's instrumentari- }\end{array}$ & 0.95 \\
$\begin{array}{l}\text { um } \\
\text { Active listening to music }\end{array}$ & 3.98 & 0.86 \\
\hline Music creation & 4.28 & 0.73 \\
\hline
\end{tabular}

According to the results presented in Table 1, the three musical activities which most contribute to children's speech development are children's singing games $(\mathrm{X}=4.58$; $\mathrm{sd}=0.58)$, counting rhyme acquisition and repetition $(\mathrm{X}=4.43 ; \mathrm{sd}=0.63)$, and song acquisition and repetition $(\mathrm{X}=4.36, \mathrm{sd}=0.70)$. The two musical activities that the respondents believe least contribute to children's speech development are playing hand-crafted rattles or instruments from a children's instrumentarium $(\mathrm{X}=3.84 ; \mathrm{sd}=0.95)$ and active listening to music $(\mathrm{X}=3.98 ; \mathrm{sd}=0.86)$. These results show that the respondents believe that the activities containing more verbal elements contribute more to children's speech development as opposed to the activities with less verbal elements, which was expected. Moreover, given that the arithmetic mean scores of all fields are higher than 3 , the results also show that most of the respondents believe that all listed activities contribute to children's speech development, rather than not. Therefore, the obtained results, displayed in Table 1, confirm the set hypothesis (H1).

Table 2. Respondents' opinions on the possible impact of creative musical and multi-modal activities on children's speech development.

\begin{tabular}{lcc}
\hline & $\begin{array}{c}\text { The } \\
\text { arithmetic } \\
\text { mean }\end{array}$ & $\begin{array}{c}\text { Std. } \\
\text { deviation }\end{array}$ \\
\hline $\begin{array}{l}\text { Activities related to sound } \\
\text { sensitivity }\end{array}$ & 4.12 & 0.82 \\
\hline Body percussion & 3.93 & 0.97 \\
\hline $\begin{array}{l}\text { Sung speech, asking musical } \\
\text { questions and completing }\end{array}$ & 4.36 & 0.76 \\
musical phrases & & \\
\hline $\begin{array}{l}\text { Varying the melody, rhythm, } \\
\text { tempo, dynamics, character }\end{array}$ & & \\
in a familiar song and & 4.01 & 0.83 \\
counting rhyme & & 0.92 \\
\hline "The Little Orchestra" & 3.86 & 0.90 \\
\hline $\begin{array}{l}\text { Activities related to making } \\
\text { sounds which fit a story or a }\end{array}$ & 4.13 & 0.81 \\
poem & & \\
\hline $\begin{array}{l}\text { Creating lyrics for an exist- } \\
\text { ing melody }\end{array}$ & 4.42 & \\
\hline $\begin{array}{l}\text { Setting a text to music } \\
\text { Multi-modal activities }\end{array}$ & & \\
\hline
\end{tabular}

As shown in Table 2, the respondents believe that out of all creative musical activities, speech development is mostly helped by the activities containing more verbal elements, such as rhythmic speech $(\mathrm{X}=4.46 ; \mathrm{sd}=0.71)$ and creating lyrics for an existing melody 
$(\mathrm{X}=4.42 ; \mathrm{sd}=0.76)$, as well as sung speech, asking musical questions, and completing unfinished musical phrases $(\mathrm{X}=4.36$; $\mathrm{sd}=0.76)$, and in the least by activities such as playing hand-crafted rattles or instruments from the children's instrumentarium - so-called The Little Orchestra $(\mathrm{X}=3.86 ; \mathrm{sd}=0.90)$, or bodypercussion $(\mathrm{X}=3.93 ; \mathrm{sd}=0.97)$. Given that all the arithmetic mean scores are above the central value on the scale, that is, three, we can conclude that the general respondents' opinion is that all creative musical activities contribute to speech development to some extent. Respondents also believe that multi-modal activities significantly contribute to speech development $(\mathrm{X}=4.23 ; \mathrm{sd}=0.73)$. The results displayed in Table 2 confirm the second hypothesis $(\mathrm{H} 2)$.

Table 3. Frequency of implementing musical activities in educational practice

\begin{tabular}{lcc}
\hline & $\begin{array}{c}\text { The } \\
\text { arithmetic } \\
\text { mean }\end{array}$ & $\begin{array}{c}\text { Std. } \\
\text { deviation }\end{array}$ \\
\hline $\begin{array}{l}\text { Counting rhyme acquisi- } \\
\text { tion and repetition }\end{array}$ & 4.14 & 0.82 \\
\hline $\begin{array}{l}\text { Song acquisition and repe- } \\
\text { tition }\end{array}$ & 4.31 & 0.76 \\
\hline $\begin{array}{l}\text { Children's singing games } \\
\text { Playing hand-crafted rat- }\end{array}$ & 4.36 & 0.83 \\
tles or instruments from a & 3.62 & 0.98 \\
children's instrumentari- & & \\
um & 3.99 & 1.04 \\
\hline Active listening to music & 3.61 & 0.96 \\
\hline Music creation & & \\
\hline
\end{tabular}

Respondents stated (as shown in Table 3 ) that the activities they most frequently conducted in practice were children's singing games $(\mathrm{X}=4.36 ; \mathrm{sd}=0.83)$ and song acquisition and repetition $(\mathrm{X}=4.31 ; \mathrm{sd}=0.76)$, as well as counting rhyme acquisition and repetition $(\mathrm{X}=4.14 ; \mathrm{sd}=0.82)$. Relatively least frequently, but still moderately often conducted, were the activities of playing hand-crafted rattles or instruments from the children's instrumentarium $(\mathrm{X}=3.62 ; \mathrm{sd}=0.98)$ and music creation $(\mathrm{X}=3.61 ; \mathrm{sd}=0.96)$.

The obtained results show that in practice, respondents more frequently conduct activities which contain more verbal elements, and for which they believe contribute to children's speech development.
Table 4. Frequency of conducting creative musical activities in educational practice

\begin{tabular}{lcc}
\hline & $\begin{array}{c}\text { The } \\
\text { arithmetic } \\
\text { mean }\end{array}$ & $\begin{array}{c}\text { Std. } \\
\text { deviation }\end{array}$ \\
\hline $\begin{array}{l}\text { Activities related to sound } \\
\text { sensitivity }\end{array}$ & $\mathbf{3 . 5 1}$ & 0.95 \\
\hline Body percussion & 3.01 & 1.08 \\
\hline $\begin{array}{l}\text { Sung speech, asking mu- } \\
\text { sical questions and com- }\end{array}$ & 2.94 & 0.99 \\
pleting musical phrases & & \\
\hline $\begin{array}{l}\text { Varying the melody, } \\
\text { rhythm, tempo, dynamics, } \\
\text { character in a familiar song } \\
\text { and counting rhyme }\end{array}$ & 3.30 & 1.07 \\
\hline "The Little Orchestra" & $\mathbf{3 . 4 0}$ & 1.14 \\
\hline $\begin{array}{l}\text { Activities related to mak- } \\
\text { ing sounds which fit a } \\
\text { story or a poem }\end{array}$ & 3.12 & 1.06 \\
\hline $\begin{array}{l}\text { Setting verses to music } \\
\text { Creating lyrics for an ex- } \\
\text { isting melody }\end{array}$ & 2.52 & 1.14 \\
\hline $\begin{array}{l}\text { Listening to music while } \\
\text { dancing /drawing painting }\end{array}$ & $\mathbf{3 . 9 7}$ & 0.93 \\
\hline
\end{tabular}

As shown in Table 4, respondents stated that they most frequently conducted the following creative musical activities: activities related to listening, mimicking, and identifying sounds $(3,51 ; \mathrm{sd}=0.95)$, "The Little Orchestra" $(x=3,40 ; s d=1,14)$, listening to music while dancing and/or drawing or painting $(X=3.97 ; \mathrm{sd}=0.93)$, and, whereas the least conducted activities were setting verses to music $(\mathrm{X}=2.52 ; \mathrm{sd}=1.14)$ and creating texts for an existing melody.

Given that, within the framework of creative musical activities, respondents conducted activities related to sound exploration and listening to music more frequently, and activities containing more verbal elements less frequently, the third hypothesis $(\mathrm{H} 3)$ was only partially confirmed. 
Table 5. Frequency of conducting multi-modal activities in educational practice

\begin{tabular}{lcc}
\hline & $\begin{array}{c}\text { The } \\
\text { arithmetic } \\
\text { mean }\end{array}$ & $\begin{array}{c}\text { Std. } \\
\text { deviation }\end{array}$ \\
\hline Frequency of integrating musi- & & \\
cal activities and linguistic & 3.90 & 0.80 \\
games & & \\
\hline
\end{tabular}

\section{Frequency of implementing}

multi-modal ways of children's

3.53

0.82

acquisition of various types of

content

Regarding the implementation of multi-modal activities in educational practice (Table 5), the respondents stated that they conducted musical activities and linguistic games very frequently $(X=3.90 ; s d=0.80)$, whereas they only sometimes conducted multi-modal adoption of various types of content $(\mathrm{X}=3.53$; $\mathrm{sd}=0.82$ ).

Given that the combination of musical activities and linguistic games at the same time represents a form of multi-modal activity, the obtained result shows that the respondents understood the concept of multi-modal activities as one containing certain other activities which they did not conduct very frequently in their educational practice, and therefore, the fourth hypothesis (H4) is also only partially confirmed.

Table 6. Correlation of the respondents' opinions on the possible impact of musical activities on children's speech development with the frequency of their implementation in practice

\begin{tabular}{lcc}
\hline & $\begin{array}{c}\text { Pearson's } \\
\text { correlation } \\
\text { coefficient }\end{array}$ & Significance \\
\hline $\begin{array}{l}\text { Song acquisition and } \\
\text { repetition }\end{array}$ & $.35^{* *}$ & .00 \\
\hline $\begin{array}{l}\text { Counting rhyme } \\
\text { acquisition and }\end{array}$ & $.19^{*}$ & \\
repetition & & \\
\hline $\begin{array}{l}\text { Children's singing } \\
\text { games }\end{array}$ & $.21^{*}$ & .02 \\
\hline $\begin{array}{l}\text { Playing hand-crafted } \\
\text { rattles or instruments } \\
\text { from a children's } \\
\text { instrumentarium }\end{array}$ & .18 & .05 \\
\hline $\begin{array}{l}\text { Active listening to } \\
\text { music }\end{array}$ & .10 & \\
\hline \begin{tabular}{l} 
Music creation \\
\hline
\end{tabular} & & \\
\hline
\end{tabular}

* Correlation is significant at the value of 0.05 (bidi-rectional).

$* *$ Correlation is significant at the value of 0.01 (bi-directional).

Table 6 shows a significant correlation between the opinions that a certain musical activity contributes to speech development and its more frequent implementation in practice. The correlation did not appear significant at the activities of playing hand-crafted rattles or instruments from the children's instrumentarium, and active listening to music.

Table 7. Correlation of the respondents' opinions on the possible impact of creative musical activities on children's speech development with the frequency of their implementation in practice

\begin{tabular}{|c|c|c|}
\hline & $\begin{array}{l}\text { Pearson's } \\
\text { Correlation } \\
\text { coefficient }\end{array}$ & Significance \\
\hline $\begin{array}{l}\text { Activities related to listening, } \\
\text { mimicking, and identifying sounds }\end{array}$ & 0.17 & 0.06 \\
\hline Body percussion & $.23^{* *}$ & 0.01 \\
\hline $\begin{array}{l}\text { Sung speech, asking musical questions } \\
\text { and completing unfinished musical } \\
\text { phrases }\end{array}$ & 0.13 & 0.16 \\
\hline $\begin{array}{l}\text { Varying the melody, rhythm, tempo, } \\
\text { dynamics, and/or character in a } \\
\text { familiar song and counting rhyme }\end{array}$ & $.26^{* *}$ & 0.00 \\
\hline $\begin{array}{l}\text { Playing hand-crafted rattles or } \\
\text { instruments from the children's } \\
\text { instrumentarium - so-called "The } \\
\text { Little Orchestra" }\end{array}$ & $.22^{*}$ & 0.02 \\
\hline $\begin{array}{l}\text { Activities related to encouraging } \\
\text { children to make sounds which fit a } \\
\text { story or a poem during their } \\
\text { performance }\end{array}$ & $.19^{*}$ & 0.03 \\
\hline Setting verses to music & 0.04 & 0.66 \\
\hline Creating lyrics for an existing melody & 0.06 & 0.53 \\
\hline $\begin{array}{l}\text { Listening to music while dancing } \\
\text { and/or drawing or painting }\end{array}$ & $.20^{*}$ & 0.03 \\
\hline
\end{tabular}

Table 7 shows the results of the study which examined whether the respondents who believed that creative musical activities contributed to children's speech development would be prepared to conduct those activities in practice more frequently. Out of nine examined creative musical activities, for five of them there was a statistically significant link between the preschool teacher's positive opinion that a certain activity contributed to children's speech development and its more frequent implementation in practice, whereas there was not any for four of the activities. As a rule, this means that if the respondents believe a certain activity contributes to speech development, they will be ready to conduct it with children in their educational practice more frequently. The activities for which there was a significant connection are body 
percussion $(\mathrm{r}=0.23 ; \mathrm{p}=0.01)$, varying melody, rhythm, tempo, dynamics, and/or character in a familiar song and counting rhyme, $(\mathrm{r}=0.26$; $\mathrm{p}<0.00)$, playing hand-crafted rattles or instruments from the children's instrumentarium - so-called "Little Orchestra" ( $\mathrm{r}=0.22$; $\mathrm{p}=0.02)$, activities related to encourage children to make sounds that fit a story or song during their performance $(\mathrm{r}=0.19 ; \mathrm{p}=0.03)$, and listening to music while dancing and/or drawing and painting $(\mathrm{r}=0.20 ; \mathrm{p}=0.03)$. Given that for most of the activities there is a significant correlation between the positive opinion of the respondents on the impact of creative musical activities on children's speech development and more frequent implementation of said activity in practice, the fifth hypothesis (H5) was partially confirmed.

One of the possible reasons for a positive connection in some activities and the lack thereof in others might be because certain activities are conducted more frequently, and are conducted for other reasons, and not only because the respondents believed they contributed to speech development. In addition, as noted above, the obtained results might also be attributed to the pre-school teachers' competencies for individual creative musical activities (Bačlija Sušić, 2018), as well as their belief in their own self-efficiency in conducting musical activities, which also affect the formation of their competencies in educational practice (Vannata-Hall, 2010; Garvis and Pendergast, 2011).

Table 8. The correlation between the opinion that multi-modal activities contribute to speech development with their frequency of implementation in practice

\begin{tabular}{|c|c|c|c|}
\hline & & $\begin{array}{l}\text { Implemen- } \\
\text { tation of } \\
\text { musical } \\
\text { activities } \\
\text { and linguis- } \\
\text { tic games in } \\
\text { praxis }\end{array}$ & $\begin{array}{c}\text { Implemen- } \\
\text { tation of } \\
\text { multimodal } \\
\text { activities }\end{array}$ \\
\hline $\begin{array}{l}\text { Multi- } \\
\text { modal } \\
\text { activities } \\
\text { contribute }\end{array}$ & $\begin{array}{l}\text { Pearson's } \\
\text { correla- } \\
\text { tion co- } \\
\text { efficient }\end{array}$ & $.24^{* *}$ & $.30^{* *}$ \\
\hline $\begin{array}{l}\text { to speech } \\
\text { develop- } \\
\text { ment }\end{array}$ & $\begin{array}{l}\text { Signifi- } \\
\text { cance }\end{array}$ & .01 & .001 \\
\hline
\end{tabular}

$* *$ Correlation is significant at the value of 0.01 (bi-directional).

When considering the correlation between the respondents' opinions on the contribution of multi-modal activities to speech development and the frequency of implementing such activities, the study showed that there was a positive correlation between these variables (Table 8). Teachers who believed that multi-modal activities contribute to speech development integrated musical activities and linguistic games more frequently in their immediate methodical practice $(\mathrm{r}=0.244$; $p=0.01)$ and used a multi-modal way of children's acquisition of various types of content more frequently $(\mathrm{r}=0.30 ; \mathrm{p}=0.0001)$. These results confirm the sixth hypothesis (H6).

\section{DISCUSSIONS}

The results obtained show that the participating graduate students of Early and Preschool Education, out of which the majority were, at the same time, preschool teachers, working in educational practice, believed that children's speech development was most strongly influenced by precisely those musical activities which contain more verbal elements, such as children's singing games and counting rhyme acquisition and repetition, which are, along with the activity of song acquisition and repetition, more frequently conducted in educational practice.

Although the participants believed that out of all creative musical activities, the activities of rhythmic speech and creating a text to accompany an existing melody influence the development of a child's speech the most, it is more common in practice to conduct creative musical activities, such as listening to music while dancing and/or drawing and painting, as well as the activities related to sound sensitivity, which may be due to the better competences of the participants in the listed areas. Frequency of implementing musical activities and creative musical activities in educational practice can be linked to the respondents' positive opinions about the impact of musical activities and creative musical activities on children's speech development and their competencies for conducting these activities as well. Respondents more frequently conducted the musical activities and creative musical activities they felt more competent for.

According to the results of the study related to self-assessment of competencies 
of preschool teachers for musical activities and creative musical activities (Bačlija Sušić, 2018), the respondents assessed their competencies for activities such as counting rhyme acquisition and repetition (55.4\%), conducting children's singing games (54.1\%), and music listening activities (54.1\%) with the highest marks, while the activity of song acquisition and repetition (46.3\%) was assessed with somewhat lesser marks. Regarding the self-assessment of competencies for creative musical activities, the respondents felt the most competent in activities related to listening, sound sensitivity and activities of listening to music while dancing and/or drawing and painting (Bačlija Sušić, 2018).

Additionally, the frequency of the implementation of music and creative musical activities in educational practice can be attributed to other reasons, not just to the respondents' belief that these activities contribute to the development of the child's speech. It can also be attributed to respondents' belief in their own self-efficiency in conducting musical activities, which furthermore affect the formation of their competencies in educational practice (Vannata-Hall, 2010; Garvis and Pendergast, 2011).

Smit (2001) states that singing, and listening to singing, relieves the child's mental tension which often causes stuttering in preschool children. In addition, the same author believes that with the development of melody awareness, speech intonation is also improved, contributing to the harmony between rhythm and intonation, which further leads to a better clarity of the message. Harmonisation of linguistic stress and the musical metre in a song improves the course of the musical meter and the understanding of verses (Gordon et al., 2011).

Child has the innate need for syncretic i.e. multimodal expression. Given the connection between speech, rhythm, movement, and music, which constitute a unique whole in language acquisition and musical activities, children's singing songs, singing games, counting rhymes, finger games, tapping rhymes, clapping games, and similar activities have a significant impact on children's speech development. Although the activities related to sound sensitivity as well as creating sound images through active listening to music do not contain any verbal elements at first glance, they are also significant in children's speech development, since through these activities, the child is encouraged to express him/herself verbally while describing his/her sonic and musical perceptions and impressions, which contributes to the acquisition of professional language, as well as the experience of literary content (Denac and Škorjanec, 2017).

These acitivites also stimulate the child to express his/her impression syncretically and multimodally (through speech, movement, image, etc.). Teachers who believed that multimodal activities contribute to speech development integrated musical activities and linguistic games more frequently in their immediate methodical practice and used a multimodal way of children's acquisition of various types of content more frequently.

Multimodal activities as a combination of different semiotic ways, such as language and music in a communicative formation or occurrence (Van Leeuwen, 2005) at the same time represent the integration of various ways and possibilities of the child's expression, which are particularly used in education. Considering that today musical experience is often multimodal, the power of music is precisely in its use as a multimodal form of communication (Way and McKerrel, 2017).

\section{CONCLUSIONS}

Based on the results of the study, we can conclude that the participating preschool teachers, the graduate students of Early and Preschool Education studies, believe that most musical and multimodal activities affect the development of children's speech.

All musical activities and creative musical activities in educational practice indirectly or directly influence children's speech development. By implementing musical activities containing more verbal elements, the child's inherent linguistic potential is developed and stimulated, along with the development of the child's musical abilities (Jäncke, 2012).

Singing of songs stimulates the formation of sounds/voice (Denac and Škorjanec, 2017) while recited (chanting) counting rhyme radiates a rhythmic freshness and richness of words which simultaneously represent a strong intellectual and musical stimulus (Jurišić and Sam Palmić, 2002). Although activities related to sound sensitivity and the activity of listening to music do not contain any verbal elements in the first place, they also contribute to the child's speech development through verbal description of musical experience. Apart from that, during musical and speech functions, several neural modules 
are activated in very similar ways (Tallal and Gaab, 2006).

Both media, language and music, offer the possibility of a child's creative expression as well. Creative musical activities, especially the ones containing more verbal elements, such as the activities of sung speech, asking musical questions and completing unfinished musical phrases, creating lyrics to an existing melody, and setting a text to music, greatly contribute to children's speech development. Creating original lyrics and songs with rhythmic movement is a child's natural activity and a natural way of his/her creative expression. Through the adoption of various songs, counting rhymes, and singing games, the child also enriches his/her vocabulary.

The development of musical and linguistic activities in a child is particularly stimulated by multimodal activities which integrate different forms of expression such as image, text, music, movement, speech, moving pictures, etc., which provide the child with the possibility of complete and spontaneous expression of musical experience. Such a rich integrated form of a child's expression at the same time represents a rich syncretic expression in various fields of art, which Vygotsky (2004) attributes to the primal form of creativity in which individual types of art were not separated or specialised but represented an indivisible whole.

The teacher's developed awareness of the significance and importance of stimulating musical and creative musical activities in children's development plays a crucial role. This awareness is also the fundamental factor influencing their frequency of use in educational practice. In addition, the teacher's developed awareness further stimulates his/her interest and motivation for further development of musical competencies (Bačlija Sušić, 2018).

The thoughts of the Japanese musical pedagogue Shinichi Suzuki best illustrate the connection of music and language, as well as their mutual influence: "When the human race created the culture of speech and writing, it also created the high culture called music. Music is a language that goes beyond speech and letters - a living art that is almost mystical. This is where its emotional impact comes in. Bach, Mozart, Beethoven - without exception they live clearly and palpably in their music, and speak forcefully to us, purifying us, refining us, and awakening in us the highest joy and emotion" (Suzuki, 2002, p.83).

\section{ACKNOWLEDGMENTS}

The article is a part of the research project Early literacy in kindergarten environment funded by the Faculty of Teacher Education, University of Zagreb.

\section{Conflict of interests}

The author declares no conflict of interest.

\section{REFERENCES}

Anvari, S. H., Trainor, L. J., Woodside, J., \& Levy, B. A. (2002). Relations among musical skills, phonological processing, and early reading ability in preschool children. Journal of experimental child psychology, 83(2), 111-130. https://doi. org/10.1016/S0022-0965(02)00124-8

Bačlija Sušić, B. (2016). Komparacija ideja funkcionalne muzičke pedagogije i temeljnih glazbenopedagoških koncepata s početka 20. stoljeća. Zivot $i$ škola: časopis za teoriju i praksu odgoja $i$ obrazovanja, 62(1), 195-206. https://hrcak.srce. $\mathrm{hr} / 165131$

Bačlija Sušić, B. (2018). Glazbene kompetencije odgojitelja u svjetlu samorefleksije studenata ranog i predškolskog odgoja i obrazovanja. [Preschool teachers' music competencies based on preschool education students' self-assessment / glazbene kompetencije odgojitelja u svjetlu samorefleksije studenata ranog i predškolskog odgoja i obrazovanja].Croatian Journal of Education: Hrvatski časopis za odgoj i obrazovanje, 20 (Sp. Ed. 1), 113-129. https://doi.org/10.15516/ cje.v20i0.3048

Barrett, M. (2006). 'Creative collaboration': an 'eminence'study of teaching and learning in music composition. Psychology of Music, 34(2), 195-218. https://doi. org/10.1177/0305735606061852

Barrett, M. S. (2011). Musical narratives: A study of a young child's identity work in and through musicmaking. Psychology of Music, 39(4), 403-423. https://doi.org/10.1177/0305735610373054

Bourne, J., \& Jewitt, C. (2003). Orchestrating debate: A multimodal analysis of classroom interaction. Reading, 37(2), 64-72. https://doi. org/10.1111/1467-9345.3702004

Chen-Hafteck, L.C. \& Mang, E. (2012) 'Music and language in early childhood development and learning'. In G. F. Welch \& G. E. Mcpherson (Ed.), The Oxford handbook of music education, (Pp. 261-278). Oxford University Press.

Dahlbäck, K. (2011). Musik och språk i samverkan-en aktionsforskningsstudie $i$ åk 1. Hög-skolan för scen och musik - HSM, [Music and language in collaboration - an action research study in 1 . year. High school for stage and music - HSM] Konstnärliga fakulteten, Göteborgs universitet. Available at: https://gupea.ub.gu.se/bitstream/2077/27887/1/gupea_2077_27887_1.pdf

Degé, F., \& Schwarzer, G. (2011). The effect of a music program on phonological awareness in preschoolers. Frontiers in psychology, 2, 124. https://doi.org/10.3389/fpsyg.2011.00124 
Denac, O. i Škorjanec, K.Z. (2017). Vloga jezika v glasbenih dejavnostih. [The role of language in musical activities], V objemu besed, 75. https:// doi.org/10.18690/978-961-286-080-6.8

Dissanayake, E. (2001). Becoming Homo Aestheticus: Sources of aesthetic imagination in motherinfant interactions. Substance, 30(1), 85-103. https://doi.org/10.1353/sub.2001.0005

Dissanayake, E. (2002). Antecedents of the temporal arts in early mother-infant interaction. In NL Wallin, B Merker and S Brown, (Ed.), The origins of music, (Pp. 389-410). Cambridge, MA: MIT Press. Available at: https://www.aacademica.org/mariana.bordoni/38.pdf

Douglas, S., \& Willats, P. (1994). The relationship between musical ability and literacy skills. Journal of Research in Reading, 17, 99-107. https://doi. org/10.1111/j.1467-9817.1994.tb00057.x

Dunbar, R. I. M. (1996). Grooming, gossip and the evolution of language. Cambridge, MA: Harvard University Press.

Finney, J. (2003). From resentment to enchantment: What a class of thirteen year olds and their music teacher tell us about a musical education. International Journal of Education and the Arts, 4(6), 1-23. Available at: http://www.ijea.org/v4n6/

Friederici, A. D. 2017. Language in our brain. Cambridge: MA MIT Press.

Garvis, S., \& Pendergast, D. (2011). An investigation of early childhood teacher self-efficacy beliefs in the teaching of arts education. International Journal of Education \& the Arts, 12(9). Available at: https://www.ijea.org/v12n9/v12n9.pdf

Gordon, R. L., Magne, C. L., \& Large, E. W. (2011). EEG correlates of song prosody: a new look at the relationship between linguistic and musical rhythm. Frontiers in psychology, 2, 352. https:// doi.org/10.3389/fpsyg.2011.00352

Grujić, G. (2017). Metodički aspekti u muzičkom vaspitanju djece predškolskog uzrasta. [Methodological aspects in the music education of pre-school children]. Beograd: Klett.

Harms, T., Clifford, R. M., \& Cryer, D. (2014). Early childhood environment rating scale. New York City: Teachers College Press. Available at: https://books.google.hr/books?hl=hr\&lr=\&id= GOsZBQAAQBAJ\&oi=fnd $\&$ pg $=\mathrm{PP} 1 \& \mathrm{dq}=\mathrm{Har}$ ms, + T., + Clifford, + R. + M., $+\% 26+$ Cryer, + D. $+(2$ 014). + Early + childhood + environment + rating $+\mathrm{s}$ cale. + New+York+City:+

Hoch, L., Poulin-Charronnat, B., \& Tillmann, B. (2011). The influence of task-irrelevant music on language processing: syntactic and semantic structures. Frontiers in psychology, 2, 112. https://doi.org/10.3389/fpsyg.2011.00112

Iverson, J. M., \& Goldin-Meadow, S. (1998). Why people gesture when they speak. Nature, 396(6708), 228. https://doi.org/10.1038/24300

Jäncke, L. (2012). The relationship between music and language. Frontiers in psychology, 3, 123. https://doi.org/10.3389/fpsyg.2012.00123

Jeremić, B. (2018). Dramski konstrukti kao dodatne aktivnosti u osnovnim školama i vrtićima. [Dramas constructs as additional activities in elementary schools and kindergartens]. Norma, (2)23, 183 196.

Jewitt, C., \& Kress, G. R. (Eds.). (2003). Multimodal literacy. New York: Lang.

Jewitt, C., Kress, G., Ogborn, J., \& Tsatsarelis, C. (2001). Exploring learning through visual, ac- tional and linguistic communication: The multimodal environment of a science classroom. Educational Review, 53(1), 5-18. https://doi. org/10.1080/00131910123753

Jurišić, G., \& Sam Palmić, R. (2002). Brojalica, snažni glazbeni poticaj. [Pulp, powerful musical stimulus]. Rijeka: Adamić doo.

Kendon, A. (1997). Gesture. Annual review of anthropology, 26(1), 109-128. https://doi.org/10.1146/ annurev.anthro.26.1.109

Kraus, N., \& Slater, J. (2015). Music and language: relations and disconnections. In Handbook of clinical neurology (129C Pp. 207-222). Elsevier. doi: 10.1016/B978-0-444-62630-1.00012-3.

Kress, G. (1997). Visual and verbal modes of representation in electronically mediated communication: The potentials of new forms of text. In I. Snyder (Ed.), Page to screen: Taking literacy into the electronic era (Pp. 53-79). Sydney: Allen \& Unwin.

Lamb, S. J., \& Gregory, A. H. (1993). The relationship between music and reading in beginning readers. Educational Psychology, 13(1), 19-27. https://doi.org/10.1080/0144341930130103

Lerdahl, F. (2001). The sounds of poetry viewed as music. Annals of the New York Academy of Sciences, 930(1), 337-354. https://doi. org/10.1111/j.1749-6632.2001.tb05743.x

Loui, P., Kroog, K., Zuk, J., Winner, E., \& Schlaug, G. (2011). Relating pitch awareness to pho-nemic awareness in children: implications for tonedeafness and dyslexia. Frontiers in psychology, 2, 111. https://doi.org/10.3389/fpsyg.2011.00111

Mercer, N., \& Littleton, K. (2007). Dialogue and the development of children's thinking: A sociocultural approach. London: Routledge.

Moyeda, I. X. G., Gómez, I. C., \& Flores, M. T. P. (2006). Implementing a Musical Program to Promote Preschool Children's Vocabulary Development. Early Childhood Research \& Practice, 8(1), n1. https://files.eric.ed.gov/fulltext/ EJ1084911.pdf

Patel, A. D. (2006). Musical rhythm, linguistic rhythm, and human evolution. Music Perception: An Interdisciplinary Journal, 24(1), 99-104. https:// doi.org/10.1525/mp.2006.24.1.99

Pramling, N., \& Wallerstedt, C. (2009). Making musical sense: The multimodal nature of clarifying musical listening. Music Education Research, 11(2), 135-151. https://doi. org/10.1080/14613800902924433

Retra, J. M. (2006). Aspects of musical movement representation in Dutch early childhood music education. In Proceedings of the $9^{\text {th }}$ International Conference on Music Perception and Cognition (ICMPC 9) (Pp1251-1256). Bologna.

Säljö, R. (2005). LS Vygotskij-forskare, pedagog och visionär. In Forsell, A. (Ed.) Boken om pedagogerna 5 (Pp 108-132). Stockholm: Liber.

Samson, S., Ehrlé, N., \& Baulac, M. (2001). Cerebral substrates for musical temporal processes. Annals of the New York Academy of Sciences, 930(1), 166-178. https://doi.org/10.3389/ fpsyg.2011.00111

Shelemay, K. K., Chazir, V., Odetta, Burgess, M., Connolly, M., Connolly, D., Morrison, M., ... Sekar Jaya (Musical group). (2001). Soundscapes: Exploring music in a changing world. New York: Norton.

Still, J. (2011). Musikalisk lärandemiljö: planerade 
musikaktiviteter med småbarn i daghem. [Musical learning environment: planned music activities with toddlers in kindergartens]. Åbo Akademi University Press, Åbo Akademi Uni-versity.

Strait, D., \& Kraus, N. (2011). Playing music for a smarter ear: cognitive, perceptual and neurobiological evidence. Music Perception: An Interdisciplinary Journal, 29(2), 133-146. https:// doi.org/10.1525/mp.2011.29.2.133

Suzuki, Sh. (2002). Odgoj s ljubavlju. [Education with Love]. Zagreb: Centar za glazbenu poduku

Šmit, M. B. (2001). Glazbom do govora. [Music to speech]. Zagreb: Naklada Haid

Tallal, P. \& Gaab, N. (2006). Dynamic auditory processing, musical experience and language development. Trends in neurosciences, 29(7), 382390. https://doi.org/10.1016/j.tins.2006.06.003

Trehub, S. E. (2003a). Musical predispositions in infancy: an update. In I. Peretz \& R. J. Zatorre (Ed.), The Cognitive Neuroscience of Music (Pp. 3-20). Oxford: Oxford University Press. Available at: https://www.researchgate.net/ profile/Robert Zatore/publication/232521640 The Cognitive Neuroscience of Music/ links/02e7e53137ab3a3c8d000000/The-Cognitive-Neuroscience-of-Music.pdf

Trehub, S. E. (2003b). The developmental origins of musicality. Nature Neuroscience, 6, 669- 673. https://doi.org/10.1038/nn1084

Trevarthen, C. (2002). Origins of musical identity: Evidence from infancy for musical social awareness. In R. A. R. MacDonald, R. J. Hargreaves \& D. Miell (Ed.), Musical identities (Pp.21-38). Oxford: Oxford University Press.

Trevarthen, C. (2012). Communicative musicality: The human impulse to create and share music. In D. J. Hargreaves, D. Miell, \& R. A. R. MacDonalds (Ed.), Musical imaginations: Multidisciplinary perspectives on creativity, performance, and perception, (Pp259-284). Oxford, UK: Oxford University Press. Available at: https://books. google.hr/books?id=qiwKUqCk1x0C\&pg=PA2 $55 \& \mathrm{lpg}=\mathrm{PA} 255 \& \mathrm{dq}=\mathrm{D} .+\mathrm{J} .+$ Hargreaves,$+\mathrm{D} .+\mathrm{M}$ iell, $+\% 26+$ R.A.R.+MacDonalds $+($ Ed. $),+$ Music al+imag-tions:+Multidisciplinary+perspectives+ on+creativity, + performance, + and + perception, \&source $=$ bl\&ots $=-\mathrm{cr}$

Trevarthen, C. \& Malloch, S. (2002). Musicality and music before three: Human vitality and invention shared with pride. Zero to three, 23(1), 10-18. https://kent.rl.talis.com/items/ A6B5E078-A669-34BA-DA95-6C2394D0B8A0.html

Van Leeuwen, T. (2005). Introducing social semiotics. Psychology Press. Taylor \& Francis e-Library. Available at: https://pdfs.semanticscholar.org/ aca7/c8ffa23c38b05faede391273a4130fc28b4a. pdf

Vannatta-Hall, J. E. (2010). Music education in Early Childhood Teacher education: the impact of a methods course on Pre-service teachers perceived confidence and competence to teach music (Doctoral dissertation). Urbana-Champagne: University of Illinois. Available at: https://www. researchgate.net/publication/45715006 Msic Education in Early Childhood Teacher Education The Impact of a Music Methods Course on Pre-service Teachers' Confidence ${ }^{-}$and Competence to Teach Music Vandivere, A. H. (2008). An investigation of the non- verbal communication behaviors and role perceptions of pre-service band teachers who par-ticipated in theatre seminars (Doctoral Dissertation). University of North Texas. Available at: https://search.proquest.com/openview/08fb2 48f36de $5 \mathrm{fb} 1 \mathrm{aa} 9 \mathrm{c} 3 \mathrm{~b} 7 \mathrm{ca} 322 \mathrm{ab} 7 \mathrm{e} / 1$ ?pq-origsite $=$ gscholar\&cbl $=18750 \&$ diss $=y$

Vygotsky, L. (1978). Interaction between learning and development. Readings on the development of children, 23(3), 34-41. Available at: https:// www.oerafrica.org/sites/default/files/L $\% 20$ $\% 26 \% 20 \mathrm{~L} \% 20$ reader section $\% 20$ one-reading 4.pdf

Vygotsky, L. S. (2004). Imagination and creativity in childhood. Journal of Russian \& East European Psychology, 42(1), 7-97. https://doi.org/10.1080 /10610405.2004.11059210

Wallerstedt, C. (2013). 'Here comes the sausage': an empirical study of children's verbal communication during a collaborative musicmaking activity. Music Education Research, 15(4), 421-434. https://doi.org/10.1080/14613808.2013.812626

Wallin N., Merker B. and Brown, S. (2000). The origins of music. Cambridge, MA: The MIT Press,

Walker, R. (2004). Cultural memes, innate proclivities and musical behaviour: a case study of the western traditions. Psychology of Music, 32(2), 153-190. https://doi.org/10.1177/0305735604041493

Way, L. C., \& McKerrell, S. (Eds.). (2017). Music as multimodal discourse: Semiotics, power and protest. London: Bloomsbury Publishing.

Wright, J. (2007). Collected poems (Weslyan poetry). Middletown: Wesleyan University Press. 